\title{
Something Was Rotten At Garden Fresh: Tax Evasion And Accounting Fraud At A Produce Wholesaler
}

William G. Brucker, Robert Morris University, USA

James E. Rebele, Robert Morris University, USA

\begin{abstract}
Most fraud cases prepared for use in auditing and fraud examination courses involve theft-ofasset or financial statement misstatement types of frauds. Based on an actual case, we present a situation where the owner of a wholesale produce business, Garden Fresh, adjusted accounting records to evade taxes. Changes in the produce industry were threatening Garden Fresh's business, and the owner used funds generated from the tax-evasion fraud to support purchases from the company's buyers. In the end, the fraud and business could not be sustained, and Garden Fresh failed. An important learning objective of the case is to illustrate how journal entries can be used to conceal a fraud, and how understanding accounting is essential for uncovering some frauds. The Garden Fresh case has been used in an undergraduate auditing class, and assessment results indicate that the case is effective for meeting identified learning objectives. The case would also be appropriate for use in taxation, fraud examination, forensic accounting, and small business courses at both the undergraduate and graduate levels.
\end{abstract}

Keywords: Tax Evasion; Accounting Fraud; Business Case Study

\section{INTRODUCTION}

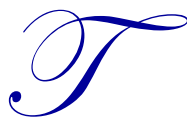

he Garden Fresh case describes a tax-evasion fraud committed at a produce company previously operating in Pittsburgh, Pennsylvania. The case is based on an actual fraud, although the names of the company and individuals have been changed. Changes in how produce is distributed in the United States led to many wholesalers losing their businesses as large grocery chains began to deal directly with growers. Caught in this change, the owner of Garden Fresh resorted to fraud as a way of generating cash and supporting the dwindling numbers of customers the wholesaler had remaining. A unique aspect of this case is that it describes a tax-evasion fraud where phony accounting entries were used to reduce the company's taxable income and tax liability. Most cases used in auditing and accounting classes are based on financial-statement fraud or embezzlement situations. The case also emphasizes how accounting entries can be used to conceal fraud and how a good auditor or manager needs to understand accounting in order to uncover fraud. The case has been used successfully in an undergraduate auditing class, and it can also be used in taxation, fraud examination, forensic accounting, or small business courses.

The following section presents the Garden Fresh case, including case questions that students are asked to answer. The section following the case provides answers to these questions, and a further section presents guidance for how the case can be used. The final section of the paper presents and discusses data gathered from students to assess the effectiveness of the case in meeting identified learning objectives.

\section{GARDEN FRESH CASE}

\section{The Produce Industry in the United States}

Fruits and vegetables are vital to the health of our nation and so therefore is the produce industry that moves these essential commodities from growers to our kitchen tables. The produce industry is fast-paced and cash- 
intensive. As soon as fruits and vegetables are picked from the field they are speedily shipped to regional wholesale produce distributors. These wholesalers in turn quickly sell the goods to local grocers in order to provide consumers with fresh produce. Consumers pay cash (or use credit cards which is, in effect, cash to the grocer) at the grocery counter when they buy these goods. This provides grocers with funds to rapidly pay wholesalers and growers to keep perishable foodstuffs flowing.

In 1930, Congress recognized the national importance of the produce industry and enacted the Perishable Agricultural Commodities Act ("PACA") to protect the growers and distributors of these goods marketed in interstate commerce. PACA governs the sale and distribution of both fresh and frozen fruits and vegetables. Companies involved in marketing these commodities must have a valid PACA license issued by the United States Department of Agriculture ("USDA"). PACA functions to facilitate fair trading, in that it helps to ensure that suppliers are paid for what they have sold and distributors get what they have ordered. Under PACA's "prompt payment terms," a supplier must be paid within ten days after the goods are accepted by the buyer, unless otherwise agreed.

\section{Operation of a Produce Company under PACA}

The PACA rules administered by the USDA require that growers assign "lot numbers" to batches of produce prior to shipment. This is done so that origin, type, quality, and nature of the fruits and vegetables can be tracked. The lot numbers are later entered into the receiving records of the wholesale distributor that accepts the merchandise.

When produce is sold by a wholesale distributor, PACA rules require that the wholesaler's salespeople enter certain information on sales tickets, including lot number, date of sale, purchaser's name, and the kind, quantity, unit price, and total selling price of the produce. Sales tickets should also display pre-printed numbers, and tickets should be used in numerical sequence. A copy of each sales ticket, including those voided, should be accounted for and maintained in the seller's records for at least two years.

Because of the PACA "ten day prompt payment terms," most wholesalers' customers were required to pay cash at the time of sale in order for the wholesaler to pay its shipper within ten days. In the era before computers, this meant that bookkeepers were needed to tally the voluminous daily sales tickets, count the cash, record the transactions, and make payments in a timely manner as prescribed by PACA.

\section{Fraud at Garden Fresh Produce Company}

For decades prior to 1990, Pittsburgh had a vibrant regional produce industry in an area known as "the Strip District," which is located along the Allegheny River. Housed in and around the five-block-long "Terminal Building," truck drivers would arrive around midnight with their loads of fresh fruits and vegetables from growers throughout the United States. Scores of wholesale produce merchants would take delivery from the truck drivers ${ }^{1}$ at the Terminal Building's docks and await their customers, mostly grocers and small produce distributors, who would buy the bulk of the fruits and vegetables before $7 \mathrm{am}$.

Like many of Pittsburgh's wholesale produce distributors in the Strip District, Garden Fresh Produce Company (Garden Fresh) was a family owned corporation that had endured the Great Depression and flourished during the decades before 1990. Its sole shareholder, Mickey Johnson, was an heir of the founders and Garden Fresh had made the family wealthy.

The produce industry began to change around 1990, in part, because of innovations in technology. For a modest investment, bookkeepers could be replaced with computers that provided cheaper, faster, and more accurate data recording and processing. Cameras and electronic surveillance could better monitor the movement of produce

\footnotetext{
${ }^{1}$ The hungry long haul truckers anxious to return to their homes wanted something to eat en route. An innovative Strip District restaurant, Primanti Brothers, developed the now famous thick meat sandwich topped with among other things coleslaw and French fries that could be eaten with one hand while driving.
} 
lots in the Terminal Building and improve control over cash sales and sales tickets. Current financial statements could be prepared in a matter of minutes rather than days.

Garden Fresh's local bank, Metropolitan Commercial Bank (MC Bank) encouraged the company to computerize its business. MC Bank had fully automated its accounting systems and offered to loan Garden Fresh the money it needed to do the same. The bankers felt it would make Garden Fresh's operations more efficient and more profitable.

Mr. Johnson respected his banker's opinion, but he also viewed the new technology as a means to escape the arduous nighttime work that regularly deprived him of sleep and put his life at odds with the rest of the world's schedule. The technology would allow him to manage Garden Fresh and his other investments from a distance, while enjoying his homes in Boca Raton, Florida and Palm Springs, California. In his absence, Johnson had a few reliable floor managers run day-to-day operations, and his trusted public accountant, Sam Barko, who had been by his side for 25 years watched over operations and the company's finances. After obtaining a loan from MC Bank, Johnson hired a consultant and replaced his outdated bookkeeping methods with a state-of-the-art computer system.

Pittsburgh's produce industry was also undergoing a fundamental change in competition. Large grocers had mostly stopped coming to the Strip District to buy their produce. Instead, they were buying their fruits and vegetables directly from the growers and having goods shipped to their own warehouses, saving the wholesaler's markup. Wholesalers, like Garden Fresh, had therefore lost their mainstay big volume customers, and were now vying for the business of lower volume "service distributors" who sold principally to restaurants and smaller grocery stores. The service distributors soon realized their newfound importance and sought better payment terms from the wholesalers. They demanded that wholesalers waive the PACA "ten day prompt payment terms" and extend the repayment period to 60-90 days if they wanted their business. Garden Fresh had little choice but to comply with this demand.

Mr. Johnson normally met monthly with MC Bank officers to review his finances and family investments. The visits were especially cordial after the computer system was installed. Mr. Johnson was pleased with its efficient operation and lavished praise on his bankers for recommending it. One quirk was that Mr. Johnson insisted that all computer printouts of Accounts Receivable and Accounts Payable subsidiary ledgers be kept locked in a cabinet in his office. Johnson's stated reason for doing this was that he did not want people to know the names of his customers and suppliers or their volume of business.

A new MC Bank branch manager, Ms. Filchock, came into Johnson's office one morning with a bank statement in her hand. As part of her new duties, Filchock was becoming acquainted with the investments of trusts Mr. Johnson had established for his children. She was shocked to discover that money was being withdrawn from the trusts on a weekly basis by the trustee, Sam Barko, Garden Fresh's accountant. The withdrawals payable to Mr. Barko over the past twelve months totaled over $\$ 200,000$. The branch manager sensed that this was wrong and asked Mr. Johnson if these withdrawals were authorized.

Outraged, Mr. Johnson immediately telephoned Mr. Barko who was unavailable. He left an angry telephone message regarding the trust withdrawals. Mr. Barko never returned the call and, instead, retained a lawyer. After threats of criminal prosecution, Mr. Barko requested a closed door meeting alone with Mr. Johnson. It seems that Barko believed he had been underpaid for his Garden Fresh work. Intimidated by Mr. Johnson, he was afraid to ask for more money. Mr. Barko therefore decided to take the money he felt he was owed from the trusts. With this explanation provided at the closed-door meeting, apparently all was forgiven by Mr. Johnson. Not only did Mr. Barko continue as Garden Fresh's accountant, but he also remained as the trustee of the family trusts and received increased fees for his work.

Garden Fresh's decision to extend 60 to 90 day credit terms to the service distributors proved to be a blunder. Freed from the PACA "ten day prompt payment terms," most of the service distributors stretched their Garden Fresh repayment terms to 90 days, and a few took as long as six months to pay their bills. Some wholesale grocers could not compete with Garden Fresh's generous credit terms and were forced out of business. All the same, Garden Fresh was paying a terrible price for its success. Garden Fresh was still required to pay its suppliers 
under the PACA "ten day prompt payment terms," but then had to wait over 90 days for payments from its Service Distributor customers. Garden Fresh risked running out of cash to finance the rapidly expanding spread between its receivables and payables.

To enable Garden Fresh to meet its cash crunch, Mr. Johnson sold his Palm Spring's home and borrowed more money from MC Bank pledging some of his other investments as collateral to secure the loan. Even with Garden Fresh's generous credit terms, however, the service distributors were struggling to pay Garden Fresh for their purchases. The service distributors complained that the big grocery chains were undercutting their customers' produce prices forcing them to slash their prices. Garden Fresh's cash crisis was getting worse.

Fearing the service distributors would fail, Mr. Johnson bought shares of stock in several of Garden Fresh's Service Distributor customers. Mr. Johnson's stock purchase provided the service distributors with cash to help them pay for their purchases from Garden Fresh. Johnson was also appointed to the service distributors' Boards of Directors, which allowed him to influence how and when these companies paid Garden Fresh as opposed to their other vendors. Johnson also wanted to ensure that they bought as much produce from Garden Fresh as possible.

To obtain the funding to purchase the stock, Mr. Johnson borrowed more money from MC Bank collateralized by his remaining investments. Garden Fresh's obligations to MC Bank now exceeded \$20 million. All of the MC Bank debt was secured by Mr. Johnson's personal wealth. Mr. Johnson was sometimes summoned to MC Bank's corporate headquarters to explain Garden Fresh's business strategy and his plans to repay the \$20 million loan.

While Garden Fresh's financial condition was becoming more strained, its computer system that a few years earlier had created operational efficiencies was now creating accounting problems. Each day, Garden Fresh's bookkeepers and clerks would input Garden Fresh's transactional activity into the computer. The daily entries would balance. Yet, two accounts would be altered by the following Monday mornings. Accounts Payable would be lowered and the account "Johnson Loan Payable" recording a loan to Mr. Johnson would be increased by the same amount, even though there was no record of Johnson having made any personal loans to Garden Fresh. No one could explain how or why this was happening. When the bookkeepers informed Mr. Barko of the problem, he just shrugged it off. Barko told the bookkeepers that the financial statements he prepared for Garden Fresh always balanced and they were the financial statements that were given to MC Bank's loan officers. Garden Fresh stopped paying Mr. Johnson his salary and instead paid him installments on his recorded loans to the company.

Example of unexplained weekend reclassification entry:

\begin{tabular}{|c|c|c|c|}
\hline Date & Account & Debit & Credit \\
\hline Weekend: June 1, 19xx & Accounts Payable & $\$ 100,000$ & \\
\hline & Johnson Loan Payable & & $\$ 100,000$ \\
\hline
\end{tabular}

Example of entry to record payment to Mr. Johnson on the newly created Johnson Loan Payable account:

\begin{tabular}{|c|c|c|c|}
\hline Date & Account & Debit & Credit \\
\hline Month: June 19xx & Johnson Loan Payable & $\$ 10,000$ & \\
\hline & Cash & & $\$ 10,000$ \\
\hline
\end{tabular}

Ultimately, two service distributors who owed Garden Fresh a total of about \$5.0 million collapsed within days of one another. Their customer bases had been eroded by the large grocery chains and the companies could no longer remain in business. The service distributors were so destitute they did not even file for bankruptcy. They just closed their doors and were gone.

With no hope of recovery, Garden Fresh's bookkeeper began to write off the $\$ 5.0$ million uncollectable Accounts Receivables owed by the two Service Distributor customers. This created an enormous loss for Garden Fresh. The Accounts Receivable write-off also exposed a strange balance sheet anomaly: Garden Fresh's total general ledger Accounts Payable balance, of \$3.7 million, now exceeded its total general ledger Accounts Receivable balance by $\$ 2.0$ million. This was rather surprising since Garden Fresh was still under the PACA "ten 
day prompt payment terms" with its suppliers. Garden Fresh had not purchased anywhere near $\$ 3.7$ million in produce from its suppliers in the past four months, let alone in the past ten days. The bookkeeper estimated that based on current activity, the general ledger Accounts Payable balance should be closer to $\$ 1.0$ million.

If the Accounts Payable balance was, in fact, accurate, MC Bank would be very concerned because there would be no way for Garden Fresh to pay the $\$ 3.7$ million of Accounts Payable from its remaining collectable Accounts Receivables of $\$ 1.7$ million. There would be a $\$ 2.0$ million cash shortfall before any loan repayments to MC Bank were factored in. Mr. Johnson knew that the fraud would now come to light.

Mr. Johnson explained to his bookkeeper that over the course of four years more than a decade ago, when Garden Fresh was highly profitable, Mr. Barko made an annual adjusting journal entry debiting Purchases and crediting Accounts Payable for $\$ 1.0$ million. In the aggregate, these adjusting journal entries increased cost of goods sold and reduced Garden Fresh's taxable income by $\$ 4.0$ million, saving the company approximately $\$ 2.0$ million in taxes. During the past twelve months, Johnson and Barko had been meeting on the weekends to undo the effects of the fictitious $\$ 4.0$ million in Accounts Payable by debiting Accounts Payable and crediting Loans Payable to Mr. Johnson. To date, they had only reduced Accounts Payable by $\$ 1.3$ million, leaving $\$ 2.7$ million of the fictitious Accounts Payable on the books. If the remaining \$2.7 million of fictitious Accounts Payable was reversed from the general ledger, the collectable Accounts Receivable would exceed the true Accounts Payable by $\$ 700,000$. The supposed cash crisis at Garden Fresh never actually existed.

Garden Fresh went from one crisis to the next as more of its Service Distributor customers went out of business. MC Bank demanded payment of its loans, and Garden Fresh was soon forced into bankruptcy. Today, the Pittsburgh produce industry is a shadow of its former self and the old Terminal Building has been torn down and replaced with townhouses.

\section{Case Questions}

1. There were four separate, although related, frauds committed at, or by, Garden Fresh. Describe each of these frauds in detail. As part of your descriptions, identify what you think is the apparent motivation for each fraud.

2. Fraud is often committed and concealed through fictitious journal entries. Johnson and Barko used fictitious journal entries to conceal two of the frauds committed at Garden Fresh. Prepare an analysis that recreates the fraudulent journal entries made by Johnson and Barko to commit and conceal the two frauds against the Internal Revenue Service (US Treasury). Your analysis should show each fictitious journal entry that Johnson and Barko made during the period when the frauds were committed. Assume that the frauds began in 19X1. Provide an analysis of the effects (to Garden Fresh's and Johnson's tax liability) of the fictitious entries.

3. The write-off of two large receivables due to Garden Fresh revealed inconsistencies between accounts receivable and accounts payable and between the accounts payable controlling account and the related subsidiary ledger. Explain the nature and significance of these inconsistencies. Although Barko, Garden Fresh's accountant, was part of the problem, explain how a more competent and ethical accountant could have uncovered the accounting inconsistencies and the related problem with accounts payable.

4. Having effective internal controls at small businesses generally requires the owner's active involvement and oversight. The problem at Garden Fresh was that the owner, Mr. Johnson, committed the frauds. Identify two internal controls that could have made it more difficult for Johnson to commit and conceal the frauds.

5. Explain why using balance sheet (permanent) accounts to conceal a fraud should make it easier for an auditor to detect the fraud. Assume that you are the auditor for Garden Fresh's bank, and you have been authorized to audit the company's financial statements prior to the bank extending additional loans. Explain how the bank's auditor could have detected frauds committed at Garden Fresh.

\section{AUTHOR INFORMATION}

William G. Brucker is an Assistant Professor of Taxation at Robert Morris University where he has taught taxation for 30 years. Brucker is also the Coordinator for the Master's of Taxation program at RMU. Brucker received his 
BA and MBA degrees from the University of Pittsburgh and his Juris Doctorate degree from Duquesne University. In addition to making presentations on forensic accounting and fraud at both practitioner and academic meetings, Brucker has published several articles in the Journal of Accounting Education. Brucker is a practicing attorney who has served as Counsel to Office of the District Attorney of Allegheny County, PA for the past 16 years. William G. Brucker, JD, MBA, CPA, Assistant Professor of Taxation, Department of Accounting and Taxation, Robert Morris University, 6001 University Boulevard, Moon Township, PA 15108 USA. Telephone: (412) 397-4083. E-mail: brucker@rmu.edu

James E. Rebele is a Professor of Accounting at Robert Morris University where he teaches auditing. Rebele received his Ph.D. from Indiana University, and he has also held faculty positions at the University of Rhode Island, the University of Kansas, Rutgers University, and Lehigh University. A previous Editor-in-Chief for the Journal of Accounting Education, Rebele has published in Issues in Accounting Education, Accounting Education: An International Journal, and the Journal of Accounting Education, as well as in other academic accounting journals. Rebele received the Lifetime Achievement Award from the British Accounting Association's Special Interest Group in Accounting Education in 2007. James E. Rebele, Ph.D., Professor of Accounting, Department of Accounting and Taxation, Robert Morris University, 6001 University Boulevard, Moon Township, PA 15108 USA. Telephone: (412) 397-6369. E-mail: rebele@rmu.edu (Corresponding author) 


\section{TEACHING NOTES}

This section presents suggested answers to the five case questions.

1. There were four separate, although related, frauds committed at, or by, Garden Fresh. Describe each of these frauds in detail. As part of your descriptions, identify what you think is the apparent motivation for each fraud.

Fraud 1: Barko embezzling approximately $\$ 200,000$ from trusts established for Johnson's children. Barko was Garden Fresh's controller and trustee for the Johnson children's trusts. Barko's motivation for taking the money was his feeling that he was being underpaid by Garden Fresh. Barko apparently could rationalize taking these funds to adjust his compensation to what he thought was "fair." Barko knew that Johnson was committing fraud; however, Johnson could not turn Barko in for the theft without exposing himself to prosecution.

Fraud 2: Garden Fresh recorded $\$ 4$ million in phony purchases and accounts payable. Since sales had not gone up (to support additional purchases), the $\$ 4$ million in phony purchases reduced taxable income by that amount, saving Garden Fresh $\$ 2$ million in taxes (federal; state). The motivation for this fraud was tax evasion. Johnson used the tax savings to increase his wealth and maintain a lavish lifestyle.

Fraud 3: Johnson (and Barko) reversed the previously-recorded, phony accounts payable entries and credited Loan Payable, Johnson for \$1.3 million. \$2.7 million in phony accounts payable remained on the books after these entries. The motivation for this fraud was again tax savings, although this time it was Johnson who personally evaded taxation. Instead of drawing a salary from Garden Fresh, Johnson took his "compensation" in the form of loan repayments. Salary would have been taxed, while loan repayments are not taxed.

Fraud 4: Fraud on MC Bank (Garden Fresh's materially misstated financial statements). At one point, Garden Fresh owed MC Bank approximately $\$ 20$ million. MC Bank was making decisions to loan Garden Fresh, in part, based on misleading financial statements. Johnson served on the boards of two service distributors, and he used his influence to generate additional purchases from Garden Fresh. This increased Garden Fresh's accounts receivable by about $\$ 5$ million, making the company seem capable of generating future cash flow to repay debt and of having increasing revenue. The problem was that the service distributors were in a precarious financial position (known to Johnson) and soon failed, defaulting on the $\$ 5$ million receivable. Johnson being on the boards for these two service distributors also created a related party issue, which should have been disclosed in Garden Fresh's financial statement footnotes. That is, MC Bank should have been informed that material sales for Garden Fresh were to companies in which Johnson had a financial interest. Johnson not taking his (material) salary also decreased expenses and increased earnings for Garden Fresh. Cash flow was, however, unaffected because Johnson was still being paid, as loan repayments in lieu of salary.

2. Fraud is often committed and concealed through fictitious journal entries. Johnson and Barko used fictitious journal entries to conceal two of the frauds committed at Garden Fresh. Prepare an analysis that recreates the fraudulent journal entries made by Johnson and Barko to commit and conceal the two frauds committed against the Internal Revenue Service (US Treasury). Your analysis should show each fictitious journal entry that Johnson and Barko made during the period when the frauds were committed. Assume that the frauds began in 19X1. Provide an analysis of the effects (to Garden Fresh's and Johnson's tax liability) of the fictitious entries.

Entries related to phony purchases and accounts payable:

19X1

$$
\begin{aligned}
& \text { Purchases } \\
& \text { Accounts Payable }
\end{aligned}
$$

$\$ 1,000,000$

$$
\$ 1,000,000
$$




$\begin{array}{llll}19 X 2 & \begin{array}{c}\text { Purchases } \\ \text { Accounts Payable }\end{array} & \$ 1,000,000 & \$ 1,000,000 \\ & \text { Purchases } & \$ 1,000,000 & \\ 19 X 3 & \begin{array}{l}\text { Accounts Payable } \\ \end{array} & & \$ 1,000,000 \\ 19 X 4 & \begin{array}{c}\text { Purchases } \\ \text { Accounts Payable }\end{array} & \$ 1,000,000 & \\ & & & \$ 1,000,000\end{array}$

\section{Notes:}

1. These recorded purchases were phony and were not made because of increasing sales.

2. Garden Fresh does not carry a large amount of inventory due to the nature of its product (produce, which spoils). Product is in one day and out the same day, or the next day. Ending inventory is therefore not affected (overstated) by these phony purchases.

3. The $\$ 4,000,000$ of phony purchases were deducted from sales, and had the effect of lowering Garden Fresh's net income and tax (federal and state) on net income. Garden Fresh's tax liability was reduced by $\$ 2$ million, saving the company cash.

4. The effect of this fraud on the accounting equation would be to increase assets by $\$ 2$ million (cash saved because of tax evasion), increase accounts payable by $\$ 4$ million, and decrease equity (lower earnings) by $\$ 2$ million.

5. The following financial information show the effects on income before tax, income tax, and net income of overstating purchases by $\$ 4$ million:

Sales

CGS (purchases)

Gross Profit

Operating Expenses

Net Income Before Tax

Income Tax (50\%)

Net Income

\begin{tabular}{rr} 
With Fraud & Without Fraud \\
\hline$\$ 20,000,000$ & $\$ 20,000,000$ \\
$11,000,000$ & $7,000,000$ \\
$9,000,000$ & $13,000,000$ \\
$2,000,000$ & $2,000,000$ \\
$7,000,000$ & $11,000,000$ \\
$3,500,000$ & $5,500,000$ \\
$3,500,000$ & $5,500,000$
\end{tabular}

Entries to write-off phony accounts payable to loan payable:

\begin{tabular}{|c|c|c|}
\hline Accounts Payable & $1,300,000$ & \\
\hline Loan Payable, Johnson & & $1,300,000$ \\
\hline
\end{tabular}

\section{Notes:}

1. This entry (or series of entries) reduced fictitious accounts payable from $\$ 4$ million to $\$ 2.7$ million.

2. Instead of salary, Johnson took his "compensation" from Garden Fresh as repayment of this phony loan.

3. Garden Fresh never made a loan to Johnson.

4. Johnson avoided paying tax on his salary; loan repayments are not taxed.

5. Garden Fresh showed higher net income because Johnson's compensation was not shown as an expense. In effect, GF was paying the tax on Johnson's salary, since loan payments were not deductible by Garden Fresh or taxed to Johnson.

6. Subsequent journal entries when Johnson was "paid" would be a debit to Loan Payable, Johnson and a credit to cash.

3. The write-off of two large receivables due to Garden Fresh revealed inconsistencies between accounts receivable and accounts payable and between the accounts payable controlling account and the related subsidiary ledger. Explain the nature and significance of these inconsistencies. Although Barko, Garden 
Fresh's accountant, was part of the problem explain how a more competent and ethical accountant could have uncovered the accounting inconsistencies and the related problem with accounts payable.

Inconsistency between accounts receivable and accounts payable:

1. Prior to the write-off of two receivables for $\$ 5$ million, Garden Fresh's accounts receivable balance was $\$ 6.7$ million. With the accounts payable balance being $\$ 5.0$ million, it appeared that GF could easily generate cash to pay its creditors. Following the write-off, accounts receivable had a balance of $\$ 1.7$ million. Following the write-off of $\$ 1.3$ million in accounts payable to Loan Payable, Johnson, the accounts payable balance was reduced to $\$ 3.7$ million. With only $\$ 1.7$ million in receivables and $\$ 3.7$ million in accounts payable, it appeared that GF had a serious cash flow problem.

2. However, $\$ 2.7$ million of accounts payable still on the books was fraudulent, so the "true" balance in accounts payable was only $\$ 1.0$ million. With $\$ 1.7$ million in receivables, GF did not actually have a cash flow crisis.

Inconsistency between accounts payable in the general ledger and the accounts payable subsidiary ledger:

1. At the time that accounts payable had a balance of $\$ 5$ million, the accounts in the accounts payable subsidiary ledger totaled to only $\$ 1$ million. That is, Garden Fresh owed its vendors a total of $\$ 1$ million, although the general ledger accounts payable balance was $\$ 5$ million because of the $\$ 4$ million in phony purchases and payables.

2. Johnson and Barko could not adjust the subsidiary ledger without (1) creating phony vendors and phony balances or (2) inflating balances due to actual vendors.

3. This inconsistency between the accounts payable controlling account and the related subsidiary ledger explains why Johnson wanted the subsidiary ledger secured. He did not want anyone noticing the inconsistency, and asking questions.

How could an accountant have discovered the inconsistencies and related problems with accounts payable?

1. Garden Fresh had to pay its vendors within ten days. At the same time, they were allowing customers longer to pay. The timing of cash inflows and outflows would mean that GF was always short of cash, and in need of external financing. An auditor could have noticed the apparent cash flow timing problem, and questioned GF about how this was being covered.

2. A simple reconciliation of the accounts payable general ledger account to the accounts payable subsidiary ledger would have revealed the inflated AP balance.

3. An accountant would have noticed that accounts payable always had a large balance, despite the company having to pay its vendors within ten days. Follow up (confirmation) with individual vendors would have detected that most of the recorded accounts payable was fraudulent.

4. Having effective internal controls at small businesses generally requires the owner's active involvement and oversight. The problem at Garden Fresh was that the owner, Mr. Johnson, committed the frauds. Identify two internal controls that could have made it more difficult for Johnson to commit and conceal the frauds.

Control 1: Garden Fresh could have a board of directors with at least one independent director. This director could be a second authorization (signer) for major transactions, such as the "loan" to Johnson. An independent director would have questioned this loan to Johnson, since GF was not receiving any asset from Johnson. The independent director could also have questioned (1) why purchases were increasing so much and (2) why accounts payable remained high when bills are payable within 10 days.

Control 2: Require second signature on all payroll checks or material checks. Problem with this is that Barko would be the likely second signator.

Control 3: Password protect accounting records to limit access to authorized personnel and to identify who was responsible for making journal entries. 
5. Explain why using balance sheet (permanent) accounts to conceal a fraud should make it easier for an auditor to detect the fraud. Assume that you are the auditor for Garden Fresh's bank, and you have been authorized to audit the company's financial statements prior to the bank extending additional loans. Explain how the bank's auditor could have detected frauds committed at Garden Fresh.

Why does using balance sheet (permanent) accounts make it easier to detect a fraud?

1. Balances in permanent accounts (assets, liabilities, equities) are not reduced to zero as part of a quarterly or annual closing process. Balances in permanent accounts carry forward to the next accounting period. For example, the phony $\$ 4$ million in accounts payable will remain on Garden Fresh's balance sheet until it is written off. Another fictitious or fraudulent entry is therefore needed to reduce or eliminate a fraudulent balance in a permanent account. In the case, accounts payable was debited for $\$ 1.3$ million and Loans Payable, Johnson was credited for $\$ 1.3$ million. This eliminated part of the fraudulent accounts payable balance, but it created another fraudulent balance in loans payable. Since the effects of the fraud remain in the permanent accounts, it would be easier for the auditor to detect the fraud.

2. Temporary accounts (revenue, expenses) are closed at the end of every accounting period. For example, the phony purchases for $\$ 4$ million would have been closed at the end of every year $(\$ 1$ million per year). The effects of the phony entries to temporary accounts therefore become hidden and harder for an accountant to detect.

How would the bank's auditor have detected the fraud at Garden Fresh? Note that there are multiple frauds here that would require different investigations. The discussion does not focus on the fraud committed by Barko, since that fraud was against the trusts.

Fraud 2: Recording phony purchases and accounts payable to reduce income and evade $\$ 2$ million in taxes.

a. An analytical test should alert the auditor to the material reduction in taxes paid, as compared to prior years. Given that revenue would have been fairly constant at the time these phony purchase entries started, the auditor's tests could have focused on the validity and valuation of purchases and operating expenses.

b. Reconciling the accounts payable controlling account to the accounts payable subsidiary ledger would have revealed the discrepancy between these records.

c. Follow up would require tracing from the AP general ledger account to the subsidiary ledger looking for vendors, which would not exist.

d. Although Garden Fresh's inventory turns over quickly, there should be a way to match purchase (AP) transactions to physical goods coming into the company. Fraudulent purchases (AP) would not match with physical goods, which would reveal the fraud.

e. Confirmation of year-end Accounts Payable and Accounts Receivable balances would have revealed the discrepancy.

Fraud 3: Journal entries to reduce accounts payable and increase loans payable to Johnson. Johnson subsequently taking loan repayments in lieu of salary.

a. This would be an unusual entry that should catch the bank auditor's attention for several reasons (1) it is for a material amount (\$1.3 million), (2) it is unusual to debit AP and credit loan payable, and (3) it appears that the owner, Johnson, is paying off the company's creditors. Creditors are normally paid from the company's cash.

b. The auditor's first step should be to talk with Johnson to get his explanation for this transaction. The explanation provided by Johnson would have to be verified by the auditor.

c. If Johnson claims to have paid off creditors, there should be a documentation trail supporting the validity of the payable and Johnson's payment. The auditor would therefore ask for such documentation, which will not exist. 
d. The auditor should also notice that Johnson is no longer being paid a salary. If the loan payable was to pay off creditors, then Johnson would still be entitled to his salary. Johnson not getting a salary should cause the auditor to question the validity of the "loan." That is, the bank auditor should ask Johnson why he is no longer being paid, and Johnson's explanation would have to be verified.

Fraud 4: Fraud again MC Bank.

Garden Fresh had fraudulent round-trip transactions where Garden Fresh and Johnson effectively created Garden Fresh's sales revenue by providing the related Service Distributors with the means to pay for the goods that they would not otherwise have purchased from Garden Fresh. The money to generate this revenue was borrowed from MC Bank by Johnson and Garden Fresh and infused into the related service distributors via Johnson's stock purchases.

Garden Fresh did not disclose the round-trip sales transactions with the related service distributors on its financial statements. The concealment of its relationship with service distributors, made a material portion of Garden Fresh's sale revenue appear to be at arm's length, improving it results of operations and therefore fraudulently induced MC Bank to make loans to Johnson and Garden Fresh.

Johnson personally bought the stock in the service distributors to conceal the relationship from MC Bank. Otherwise it would have shown as an investment on Garden Fresh's balance sheet.

Garden Fresh's \$4.0 million tax evasion scheme was not disclosed to MC Bank. An indictment of Johnson, Barko, and Garden Fresh for tax evasion would have a material adverse affect on Garden Fresh's operations and increased MC Bank's risk of it loans not being repaid. Income tax evasion crimes can be charged many years after the commission of the fraud since the IRS argues that the statute of limitations does not run when a false tax return is filed. MC Bank would not have made the loans if this disclosure had been made.

Johnson not taking his (material) salary decreased expenses and increased earnings for Garden Fresh. This mislead MC Bank as to Garden Fresh's profitability. Garden Fresh's cash flow did not improve as a result of the increased earnings since Johnson was taking cash payments equivalent to his former salary from phony loan repayments.

\section{IMPLEMENTATION GUIDANCE}

The Garden Fresh case was used in an introductory auditing class in the Spring 2013 semester. Students were provided with guidelines for answering the case questions and preparing their reports (Appendix A). The seven-page rule for case reports was intended to counter some students' tendency to write too much and to have students focus their answers on the questions. Encouraging students to bullet-point answers was intended to focus students' answers and to make grading easier.

The guideline sheet also identifies some grading criteria, and how the cases would be graded was discussed in class. Despite identifying specificity of answers as a grading criterion, some groups' answers were vague and failed to incorporate specific information from the case. Deducting points for each misspelled word was intended to have students proofread their papers, and this was discussed in class. Again, though, some groups' papers still contained misspelled words. These outcomes indicate that the guidance provided to students, or the penalty for noncompliance, will have to be changed when the case is used in future classes.

Students completed the case in self-selected groups of three. Students were given three weeks to complete the case, which was sufficient time for the assignment. The case was discussed in class on the date that students turned in their reports. The class period where the case was discussed was 75 minutes, but the case could be discussed in a 50-minute class. Providing handouts for some case questions (e.g., journal entries) would reduce the time needed to discuss the case. 
The Garden Fresh case has been used in an introductory auditing course, although it could also be used in fraud examination, forensic accounting, taxation, and small business courses. Students need an understanding of accounting for sales/accounts receivable and purchases/accounts payable, which would be covered in the introductory financial accounting course. No specific tax knowledge is required to complete the case, although students need to recognize how the accounting entries would affect taxable income and tax liability.

\section{ASSESSMENT}

To evaluate whether the Garden Fresh case enhanced students' learning experience in the auditing class, we asked students to complete an 11-question survey instrument. The survey instrument is presented as Appendix B. Questions were answered on a scale of $1-5$, with 1 being used to indicate that a student strongly disagreed with a statement and 5 indicating that the student strongly agreed with the statement. In addition to measuring how effectively the case met learning objectives, the survey also asked students to evaluate case understandability, the time allowed to complete the case, and guidance provided by the instructor. Students were also asked about the relevance of the case to the auditing class and whether they would recommend using the case in future classes.

Results from the student survey are presented below in Table 1. Thirty-two students in an introductory auditing course completed the survey. Overall, the students' survey responses indicate that the Garden Fresh case is effective for meeting identified learning objectives. Specifically, students viewed the case as a valuable learning experience (mean of 3.84) and as effective for reinforcing textbook coverage using a realistic situation (mean of 3.94). The case also helped students understand different motivations for committing fraud (mean of 4.09), how journal entries can be used to conceal fraud (mean of 3.94), and the problems associated with designing and implementing effective internal controls in small business. The case was less effective for helping students learning how to design audit tests for uncovering fraud (mean of 3.38).

Students' responses generally indicated that three weeks was sufficient time to complete the case (mean of 3.81). Lower average responses were obtained for case questions being clearly worded (mean of 3.13) and guidance for completing the case being clear and adequate (mean of 3.44). Despite these shortcomings, students generally recommended using the Garden Fresh case in future classes (mean of 3.63).

Overall, the assessment results show the Garden Fresh case to be a relevant and effective learning experience. Improvements can be made, however, in case question wording, in the guidance provided to students, and in emphasizing how audit tests can uncover the types of fraud found in the case.

Table 1

\begin{tabular}{|ll|c|}
\hline \multicolumn{2}{|c|}{ Results from Student Assessment Survey } & Mean \\
\hline \multicolumn{1}{|c|}{ Survey Question } & 3.84 \\
\hline 1. & Overall, completing the Garden Fresh case was a valuable learning experience: & 3.94 \\
\hline 2. & The case was effective as a means of reinforcing textbook coverage of fraud in a realistic situation: & 4.09 \\
\hline 3. & Completing the case helped me understand different motivations for committing a fraud: & \multirow{2}{*}{4.16} \\
\hline 4. & $\begin{array}{l}\text { Completing the case helped me understand the difficulty of designing and implementing effective internal } \\
\text { controls in small businesses: }\end{array}$ & 3.94 \\
\hline 5. & The case was an effective way to illustrate how fraud can be concealed through journal entries: & 3.38 \\
\hline 6. & The case helped me learn how to design audit tests to search for different means for committing fraud: & 3.81 \\
\hline 7. & The time allowed three weeks) for completing the case was adequate: & 3.13 \\
\hline 8. & Case questions were clearly worded and easily understood: & 3.44 \\
\hline 9. & Guidance for how to write the case report was clear and adequate: & 3.84 \\
\hline 10. & The case was interesting and relevant to the auditing course: & 3.63 \\
\hline 11. & I would recommend using the Garden Fresh case in future classes: & \\
\hline
\end{tabular}




\section{APPENDIX A}

\section{Something was Rotten at Garden Fresh: Fraud at a Produce Wholesaler Case Completion Guidance}

1. The due date for the case is Wednesday, April 24, 2013. Late case submissions will not be accepted.

2. Cases cannot be more than seven pages long, double-spaced with appropriate margins. A 12-point font must be used. Bullet-point answers where appropriate. For example, the answer to case question 4 should be answered:

Internal Control 1:

Internal Control 2:

Internal Control 3:

3. Cases must be completed in teams of three students. You may self-select your teammates, and you are permitted to work with a student in another section of the course. Names for self-selected teams must be turned in to the course instructor by Monday, April 1, 2013. The instructor will then assign to teams students who have not self-selected.

4. Cases will be graded on the basis of comprehensiveness, correctness, specificity and relevance of answers, and writing quality. Answers must be specific to the Garden Fresh case, as opposed to being generic, textbook, answers. Proofread your case analysis before submitting it for grading. Points will be deducted for each misspelled word.

5. External sources for material in your paper must be referenced by (1) identifying where you are relying on an external source and (2) proving a reference list of sources. For example, suppose that you use the course textbook as a source for internal control information. You would insert, parenthetically, the authors' names and publication date at that point in the paper where you are relying on the external source. For example, According to Arens, Elder, and Beasley (2012, page 298), separation of duties is an effective control for.... Direct quotes (which should be used sparingly) must be in quotation marks. All referenced works must be listed at the end of your paper in the following format: Arens, A. A., R. J. Elder, and M. S. Beasley, 2012, Auditing and Assurance Services: An Integrated Approach, Prentice-Hall.

6. The instructor is available to answer questions about the case, although answers to specific case questions cannot be provided. If you are in doubt about what to do or how to do something, please contact the instructor for guidance. 


\section{APPENDIX B}

\section{Garden Fresh Fraud Case: Assessment Questionnaire}

The following questions relate to the Garden Fresh case that you recently completed. Please answer each question by circling the number that represents your opinion about different aspects of the case. Results of the questionnaire, which are anonymous, will be used to make improvements to the case.

1. Overall, completing the Garden Fresh case was a valuable learning experience:

$\begin{array}{ccccc}\text { Strongly Disagree } & \text { Disagree } & \text { Neither Agree or Disagree } & \text { Agree } & \text { Strongly Agree } \\ 1 & 2 & 3 & 4 & 5\end{array}$

2. The case was effective as a means of reinforcing textbook coverage of fraud in a realistic situation:

$\begin{array}{ccccc}\text { Strongly Disagree } & \text { Disagree } & \text { Neither Agree or Disagree } & \text { Agree } & \text { Strongly Agree } \\ 1 & 2 & 3 & 4 & 5\end{array}$

3. Completing the case helped me understand different motivations for committing a fraud:

$\begin{array}{ccccc}\text { Strongly Disagree } & \text { Disagree } & \text { Neither Agree or Disagree } & \text { Agree } & \text { Strongly Agree } \\ 1 & 2 & 3 & 4 & 5\end{array}$

4. Completing the case helped me understand the difficulty of designing and implementing effective internal controls in small businesses:

$\begin{array}{ccccc}\text { Strongly Disagree } & \text { Disagree } & \text { Neither Agree or Disagree } & \text { Agree } & \text { Strongly Agree } \\ 1 & 2 & 3 & 4 & 5\end{array}$

5. The case was an effective way to illustrate how fraud can be concealed through journal entries:

$\begin{array}{ccccc}\text { Strongly Disagree } & \text { Disagree } & \text { Neither Agree or Disagree } & \text { Agree } & \text { Strongly Agree } \\ 1 & 2 & 3 & 4 & 5\end{array}$

6. The case helped me learn how to design audit tests to search for different means for committing fraud:

$\begin{array}{ccccc}\text { Strongly Disagree } & \text { Disagree } & \text { Neither Agree or Disagree } & \text { Agree } & \text { Strongly Agree } \\ 1 & 2 & 3 & 4 & 5\end{array}$

7. The time allowed (three weeks) for completing the case was adequate:

$\begin{array}{ccccc}\text { Strongly Disagree } & \text { Disagree } & \text { Neither Agree or Disagree } & \text { Agree } & \text { Strongly Agree } \\ 1 & 2 & 3 & 4 & 5\end{array}$

8. Case questions were clearly worded and easily understood:

$\begin{array}{ccccc}\text { Strongly Disagree } & \text { Disagree } & \text { Neither Agree or Disagree } & \text { Agree } & \text { Strongly Agree } \\ 1 & 2 & 3 & 4 & 5\end{array}$

9. Guidance for how to write the case report was clear and adequate:

$\begin{array}{ccccc}\text { Strongly Disagree } & \text { Disagree } & \text { Neither Agree or Disagree } & \text { Agree } & \text { Strongly Agree } \\ 1 & 2 & 3 & 4 & 5\end{array}$


10. The case was interesting and relevant to the auditing course:

$\begin{array}{ccccc}\text { Strongly Disagree } & \text { Disagree } & \text { Neither Agree or Disagree } & \text { Agree } & \text { Strongly Agree } \\ 1 & 2 & 3 & 4 & 5\end{array}$

11. I would recommend using the Garden Fresh case in future classes:

$\begin{array}{ccccc}\text { Strongly Disagree } & \text { Disagree } & \text { Neither Agree or Disagree } & \text { Agree } & \text { Strongly Agree } \\ 1 & 2 & 3 & 4 & 5\end{array}$

Thank you for completing the survey 
NOTES 